\title{
Habitat selection of Marbled Teal and White-headed Duck during the breeding and wintering seasons in south-eastern Spain
}

\author{
ESTHER SEBASTIÁN-GONZÁLEZ, CRISTINA FUENTES, \\ MARCOS FERRÁNDEZ, JOSÉ L. ECHEVARRÍAS and ANDY J. GREEN
}

\begin{abstract}
Summary
Understanding habitat requirements is vital for developing successful management strategies for threatened species. In this study we analyse the habitat selection of two globally threatened waterbirds (Marbled Teal Marmaronetta angustirostris and White-headed Duck Oxyura leucocephala) coexisting in an internationally important wetland (El Hondo Natural Park, south-eastern Spain) at three spatial scales. We surveyed adults and broods of these species fortnightly during two consecutive years and we related density and presence of birds to several habitat variables. At a pond-selection scale, the density of both species was related to the surface area of the ponds, with Marbled Teal showing avoidance of medium-sized ponds, and White-headed Ducks strong selection for the largest ponds. Within ponds, Marbled Teal avoided open waters, and was mainly associated with Phragmites reedbeds, but also selected areas with saltmarsh and Scirpus vegetation, especially for brood-rearing. White-headed Duck made more use of deeper areas with open water, especially in winter, and Phragmites was the only emergent vegetation with which it associated. When breeding success was very high in 2000, strong creching of broods was observed in White-headed Duck, but not in Marbled Teal. In order to provide suitable habitat for both species, there is a need to maintain spatial diversity with a combination of large wetlands suitable for both species and small, vegetated ones suitable for the Marbled Teal.
\end{abstract}

\section{Introduction}

The analysis of habitat selection patterns in birds has a long tradition (Hildén 1965, Block and Brennan 1993) and provides vital information for the development of appropriate species management strategies (Caughley 1994). A precise knowledge of habitat preferences is especially important for threatened species (Mildenstein et al. 2005, Onorato et al. 2010). However, when a species is scarce it is often difficult to obtain good quality data. For these species any information can be important for managers as an orientation tool.

Marbled Teal Marmaronetta angustirostris and White-headed Duck Oxyura leucocephala are globally threatened waterbirds (BirdLife International 2008a,b). The White-headed Duck has been severely affected by hunting and habitat destruction and has suffered an important decline (Green and Anstey 1992, Green and Hughes 2001). The world population is now < 10,000 individuals in Eastern Asia and the Western Palearctic and it is considered "Endangered" by IUCN (Birdlife International 2008a). The Spanish population is relatively stable at around 2,500 birds (Ballesteros et al. 2008), but threatened by hybridisation with the introduced North American Ruddy Duck O. jamaicensis (Muñoz-Fuentes et al. 2007) and by low genetic diversity (MuñozFuentes et al. 2005, 2008). Marbled Teal is classified as "Vulnerable" by IUCN, with a global population of about $14,000-26$, ooo individuals (BirdLife International 2008b). The current situation 
of the Marbled Teal in Western Europe is particularly bad, with a declining population now $<30$ breeding pairs in the east and south of Spain (Ballesteros et al. 2008, unpublished national census for 2010).

The study of Marbled Teal and White-headed Duck is difficult because of their small population sizes. It is especially complicated for the Marbled Teal due to its cryptic behaviour. To date, there have been relatively few studies on habitat selection of either species. Existing studies have been carried out over short periods of several weeks, or were made on relatively small numbers of birds (Amat 1984, Green 1998a, Green et al. 1999a, Green and El Hamzaoui 2000, Armengol et al. 2008). Here we present a unique study of habitat selection by both species during the course of two annual cycles in a wetland complex that has been the most important breeding site in Western Europe for both of them. This study is especially important because it was performed during years when the populations of both species were unusually large (Fuentes Sendín 2005). In more recent years, it would not be possible to perform a similar study owing to smaller population size, especially for the Marbled Teal.

In this study we evaluate habitat selection in relation to wetland size, the quantity and type of vegetation, and water depth. All these variables are key determinants of habitat use by the Marbled Teal (Green 1998a, Green and El Hamzaoui 2000) and the White-headed Duck (Amat 1984, Castro et al. 1994). As both species use the studied wetlands for breeding, feeding and resting, the habitat selection patterns found refer to the three processes together. We compare the habitat selection observed for broods and adults for both Marbled Teal and White-headed Duck. We perform analyses at three spatial scales: selection at pond, macrohabitat and microhabitat levels. We discuss the implications of our findings for the conservation of the two species.

\section{Methods}

\section{Study area}

The study was performed in El Hondo (2,387 ha) and Salinas de Santa Pola $(2,470$ ha) Natural Parks in south-eastern Spain (Figure 1a). El Hondo is a semi-natural wetland with meso-saline and poly-saline waters. The wetland is formed by two large central ponds (Poniente and Levante) surrounded by dykes, channels and 15 small ponds. The central ponds are used for irrigation while the surrounding ponds are hunting areas. The water in the ponds comes from the Segura River (which has high concentrations of organic matter) and from agricultural drainage. Santa Pola is formed by solar salt exploitation and several ponds used for fishing and hunting. Both natural parks are internationally important wetlands for many species of waterbirds. They are Ramsar sites and are protected by the European Habitat and Bird Directives (Directives 92/43/CEE and 79/409/CEE, respectively). Thousands of migrants use the parks in winter (Martí and del Moral 2003) and they are also important breeding sites for many species (Martí and del Moral 2004). The vegetation is dominated by the reed Phragmites australis (Cirujano et al. 2005), but there are also important saltmarshes and areas with Scirpus litoralis and S. maritimus. Submerged vegetation is dominated by Potamogeton pectinatus and Ruppia spp. The most abundant fish are Mugil cephalus, Anguilla anguilla, Liza ramada, Gambusia affinis and Cyprinus carpio (Torralva et al. 2002). The area has a semi-arid climate with low average annual precipitation $(280 \mathrm{~mm})$ concentrated in a few days. The mean annual temperature is $18^{\circ} \mathrm{C}$, with hot summers (mean temperature in August $26^{\circ} \mathrm{C}$ ) and mild winters (mean January temperature $11^{\circ} \mathrm{C}$ ). In years of drought, the large ponds sometimes dry out completely (Melendez-Pastor et al. 2010).

\section{Bird surveys}

Marbled Teal and White-headed Duck were surveyed every month between 1998 and 2000 (every 7-15 days during the breeding season, depending on the availability of surveyors). Access was difficult since most ponds are found on private hunting estates that are only willing to give 

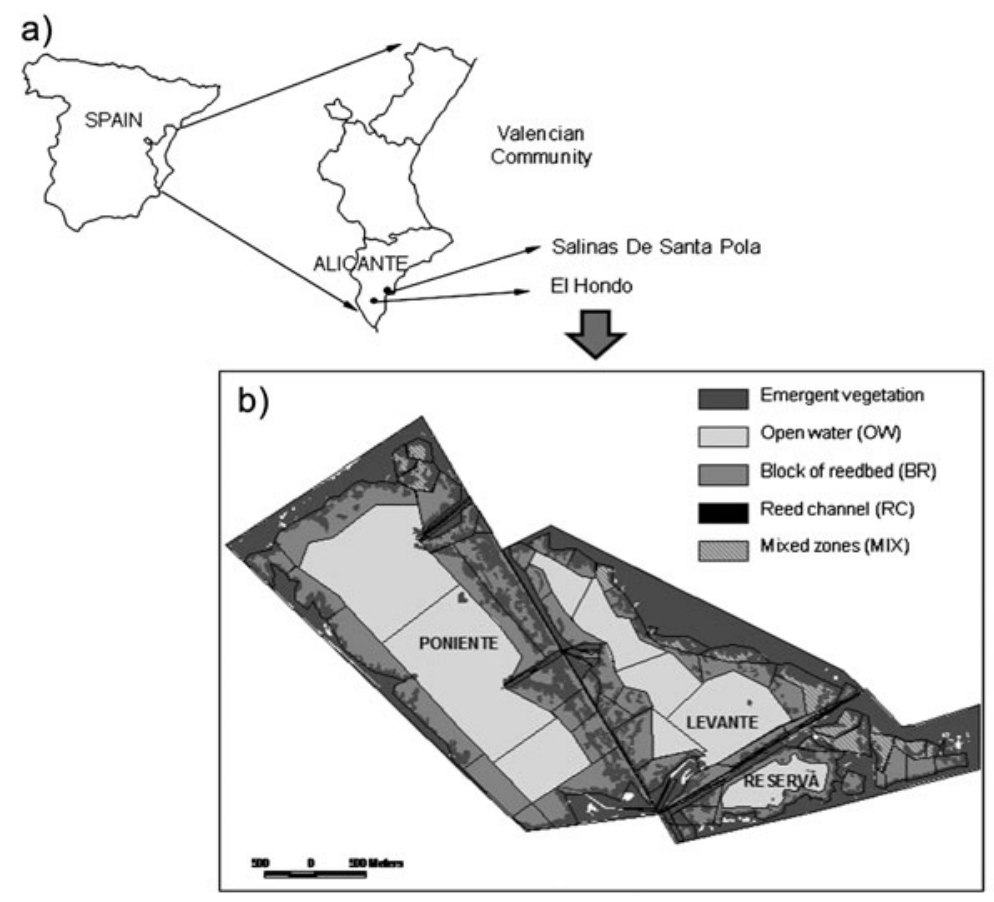

Figure 1. Study area. a) Location of the Salinas de Santa Pola and El Hondo Natural Parks in Alicante province (south-eastern Spain). b) Map of El Hondo with the three largest lagoons representing emergent vegetation (unavailable habitat) and the four main different habitats accessible for the study species.

occasional, limited access. Hence the number of areas visited varied considerably. Surveys were performed by experienced observers using binoculars and telescopes from the shore, from elevated observation points or from small boats. Owing to access problems, only part of the surface area of many ponds could be censused.

The numbers of adults, flocks, broods and chicks were counted for both species. Chick age was estimated (Green 1998b). Brood size was calculated as the number of chicks per brood, considering only small chicks of less than 15 days. Although there is likely to be some early-chick mortality, this measure appeared to present the best trade-off between the estimation of chick size and the original brood size. Flocks were defined as groups of individuals separated by no more than 1o $\mathrm{m}$. For each analysis, we used the information regarding flocks or individuals depending on data availability. We analysed habitat selection at pond and macrohabitat level using individuals as the dependent variable, while flocks were used for the microhabitat level of study. We excluded from the analyses those surveys covering less than $65 \%$ of the area available for waterbirds at each specific pond, and those areas surveyed less than three times per survey period (see below). However, we knew from previous studies (Navarro and Robledano 1995) and from personal observations in previous years that the most important areas for the two species were included in the study. The information from observations in a network of narrow irrigation channels connecting different ponds was only used for calculating the average brood sizes and for the study at microhabitat level. Broods are often observed in these irrigation channels (Green et al. 1999b).

We divided the surveys into four periods: Winter 1998-1999 (September 1998-March 1999), Summer 1999 (April-August 1999), Winter 1999-2000 (September 1999-March 2000) and Summer 2000 (April-August 2000). 
Data quality changed over time during the study period. A reduction in the number of participants in the surveys and in access to the wetlands reduced the number of ponds surveyed and the number of bird observations in winter 1999-2000 and summer 2000. Moreover, in summer 2000, exceptional breeding success increased the number of broods detected. Given this changing availability of data, we used varying time periods to meet the different study objectives. In each case, we specify which information was used.

\section{Habitat variables}

To analyse habitat selection at pond level, we measured the total surface of the pond in hectares (logarithmically transformed) based on aerial photographs, the average depth of the surveyed area in $\mathrm{cm}$, the proportion of the surface surveyed (with water presence but not occupied by emergent vegetation) and the proportion of the surface covered by Phragmites reed in relation to the rest of the vegetation or bare areas. Variables were measured using ArcView 3.2 in the larger areas (ponds $>50 \mathrm{ha}$ ), while for small areas (ponds $<50 \mathrm{ha}$ ) we made a visual estimation. All visual estimations of habitat variables were made by the same observer (C. Fuentes). We related pond characteristics to bird density measured as the number of individuals per 100 ha (using only the surface of the area that was surveyed). We used the average values per pond and period for each variable. We performed the analyses at pond level using information from winter 1998-1999 and summer 1999 because the number of ponds accessed in the other periods was too low to permit analyses with a minimal statistical power.

The macrohabitat analysis was carried out only for the three largest ponds, which could be more easily accessed and held the most birds. In these ponds, we identified four main habitats (Fig $\mathrm{Ib}$ ): open water central areas with the greatest depths (open water, $\mathrm{OW}$ ), smaller areas of open water surrounded by reed formations (Block of reedbed, BR), artificial channels surrounded by reed (reed channels, RC), and shallow zones of mixed emergent and saltmarsh vegetation that often dry out (mixed zones, MIX). We performed the analyses at macrohabitat level using data from the four study periods.

We also performed a more detailed microhabitat analysis by identifying the depth and the vegetation associated with each flock observation. We pooled the information for the two studied years for each season (i.e. winter and summer). We identified the position of the flock in the pond. A flock was identified as in open water when the minimum distance to the shore or the emergent vegetation was estimated to be $\geq 15 \mathrm{~m}$. For flocks closer to the shore we identified the dominant vegetation (reed, saltmarsh or Scirpus spp.), or bare shoreline. Depth was visually estimated based on the height to which water reached on the legs or body of nearby waterbirds (e.g. Black-winged Stilt Himantopus himantopus, Greater Flamingo Phoenicopterus ruber), or directly measured when possible.

\section{Statistical analyses}

We calculated the abundance and density of birds using the average number of individuals counted in the census, for each year and period. To test if survey effort was correlated with estimated bird density we used Spearman correlation tests to relate the number of surveys (per pond and survey period) to the average density of individuals and broods.

We created habitat-dependent models following the two steps described in Wintle et al. (2005). When relating the dependent variable and the independent environmental variables, it can be difficult to know a priori whether a particular relationship between the variables is likely to be linear, quadratic, cubic or otherwise. The inclusion of very complicated responses which are not justified by the data could produce models with a lack of biological meaning. Therefore, Wintle et al. (2005) recommend a first step that consisted of a visual inspection of the shape of each of the independent variables before incorporating them in the model, so as to include the variables with 
the most appropriate shape. We used generalised additive models (GAM; Hastie and Tibshirani 1990) in R 2.1.I (R Development Core Team 2007) for this visual inspection analysis. As a second step, we used generalised linear models (GLM; McCullagh and Nelder 1989) to relate pond characteristics to bird density. We measured bird density as the number of birds per 10o ha, ranked to normalise the variable. We performed multivariate GLMs and we selected the model with the lowest AIC (Akaike's Information Criterion), which included only significant variables $(P<0.05)$. This criterion selects the most parsimonious model that has the highest explained deviance with the lowest number of variables. We constructed all the possible models, including their quadratic effects and selected the most parsimonious model. Models were considered equivalent when the variation was lower than two points of AIC (Burnham and Anderson 1998). The normal distribution was used as an error function and logarithm as the link function.

We constructed the models separately by species (White-headed Duck and Marbled Teal) and developmental stage (adults and broods). Moreover, as there may be seasonal variations in flock size, we also created separate models for both breeding and wintering periods. We used Pearson correlation to test variables for collinearity before analyses.

Macrohabitat selection was analysed using the Savage Selectivity Index (Manly et al. 1993, Ursúa et al. 2005) calculated as $w i=U i / p i$, where $p i$ is the proportion of available and surveyed habitat and $U i$ is the proportion of observations per period and habitat type. This index indicates the differences in the preference of the ducks, comparing between several macrohabitat types. Since the index is calculated as a relative value considering all the evaluated habitat types; the values obtained are comparable within the same group (in our case, the values are comparable for the same season, developmental stage and species). The values for wi vary from o (maximum negative selection) to infinity (maximum positive selection). When $w i=1$ there is no selection. The significance of $w i$ values was tested with $\chi^{2}$ (see Manly et al. 1993 for a description of the procedure). We performed the analyses for both adults and broods. We applied the Bonferroni correction for the number of $\chi^{2}$ performed tests. For the Bonferroni correction, we consider as a family of statistical tests all the analyses performed for the same season, developmental stage and species.

\section{Results}

\section{Flock and brood information}

We performed 666 valid surveys of individual wetlands that met the conditions to be included in the analyses. We counted a total of 2,824 Marbled Teals and 5,361 White-headed Ducks (see Table I for detailed information).

The average flock and brood sizes for the Marbled Teal and the White-headed Duck differed consistently between species (Table 1 , all $\chi^{2}>6.86$ and all $P<$ o.01), except in summer 2000

Table 1 . Summary of the surveys performed, showing the total number of surveyed adults and broods in each period, and the total number of surveys performed per period (n). We also show average ( \pm SD) brood and flock sizes for the species studied. Because of differing data distributions, flock size is represented by the geometric mean and brood size by the arithmetic mean.

\begin{tabular}{lclcl}
\hline & Marbled Teal & $n$ & White-headed Duck & $n$ \\
\hline Wintering adults (1998-1999/ 1999-2000) & $299 / 297$ & $288 / 88$ & $1,190 / 2,864$ & $288 / 88$ \\
Breeding adults (1999/ 2000) & $1,176 / 825$ & $381 / 108$ & $467 / 778$ & $381 / 108$ \\
Broods (1999/ 2000) & $27 / 35$ & & $44 / 183$ & \\
Average flock size ( \pm SD) & $2.28 \pm 0.19$ & 593 & $2.67 \pm 0.35$ & 394 \\
Maximum flock size & 98 & & 976 & \\
Average brood size ( \pm SD) & $6.75 \pm 4.05$ & 56 & $2.81 \pm 2.33$ & 206 \\
Maximum brood size & 16 & & $\geq 70^{*}$ & \\
\hline
\end{tabular}

${ }^{*}$ This value represents creching (the amalgamation of several broods) at the end of the breeding period. 
when flock size was similar. The largest groups for both species appeared in the non-breeding season (September-February) (Figure 2).

Brood size tended to decrease with time for Marbled Teal (Pearson correlation test, $r=-0.413$, $P=0.071)$ but increased with time for White-headed Duck $(r=0.355, P=0.046$, Figure 3$)$.

\section{Survey effort and pond selection}

We did not find significant correlations between the number of surveys per time and site, and the average density for Marbled Teal adults, Marbled Teal chicks and White-headed Duck adults in each season (Spearman correlation tests, all $P>0.2$ ). The correlation was significant for the White-headed Duck density of chicks and the survey effort $(r=0.344, P=0.022)$. However, this correlation became non-significant when using only data from summer 1999, when the number of ponds surveyed was higher.

We excluded both percentage reed and average depth from the pond selection analysis because they were highly positively correlated with pond size. All the GLM models related the density of Marbled Teal and White-headed Duck with the size of the ponds (Tables 2 and 3). The best model for breeding White-headed Ducks also retained the percentage of open water as an explanatory variable. Most of the models included the variable as a quadratic term, indicating an avoidance of medium-sized ponds by Marbled Teal, and a strong preference for the largest ponds by Whiteheaded Ducks (Figure 4).

\section{Macrohabitat selection}

Marbled Teal adults generally avoided open water and seemed to positively select areas with reed, both in the main central areas of the ponds and in the peripheral channels (Table 4). The mixed habitat was also positively selected in the breeding season and in one of the winters. White-headed Duck adults selected open water and tended to avoid areas with reed in winter. In the breeding season they avoided mixed areas, while their preferences for the rest of the areas depended on the year. The broods of both species avoided open water (Table 5) and White-headed Duck broods selected areas with reeds, while Marbled Teal broods selected areas of mixed vegetation.

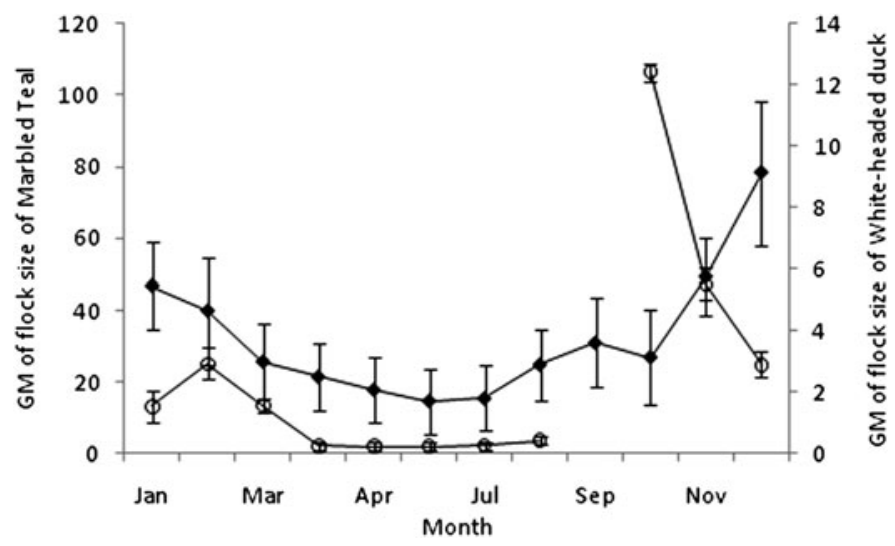

Figure 2. Seasonal changes in flock size of Marbled Teal (open circles) and White-headed Duck (solid circles) showing geometric means $(\mathrm{GM}) \pm$ gse (geometric standard error). Note the difference in the scale between species. There were insufficient data for Marbled Teal in September. 

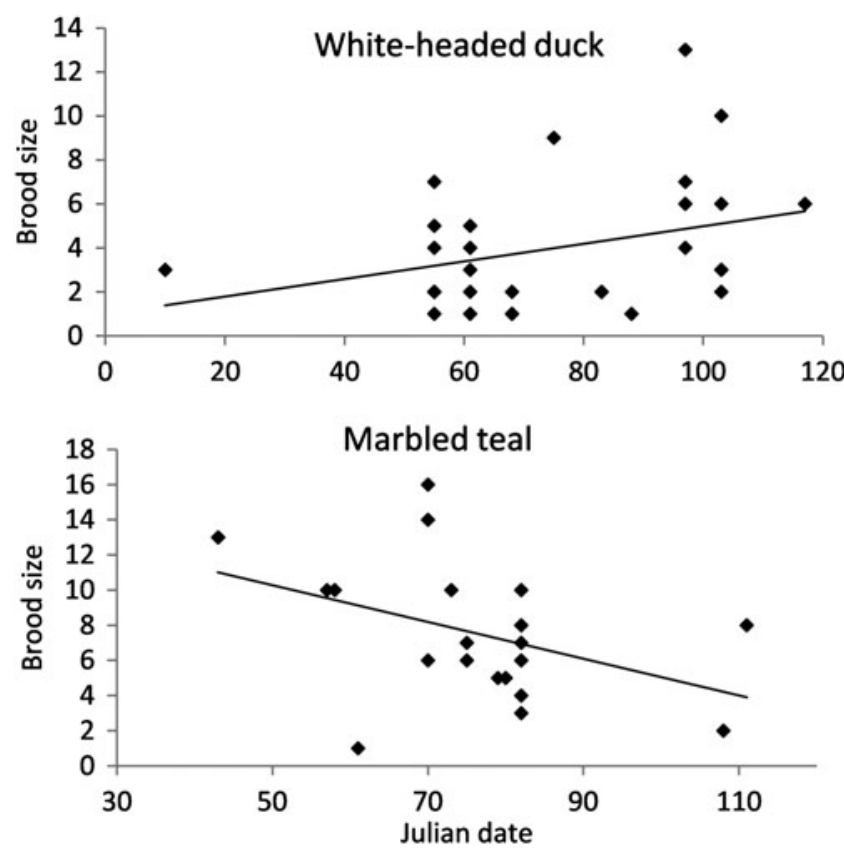

Figure 3. Brood size changes over time in 2000 (represented as the calendar date, $1=01 / 04 /$ 200o) for Marbled Teal and White-headed Duck. We considered only broods with small chicks of estimated age $<15$ days. Linear regression of the data is also represented. Each point represents one observation.

\section{Microhabitat selection}

The microhabitat analysis showed that flocks of both species were highly associated with Phragmites reed formations in the breeding and wintering seasons and also for broods (Figure 5). The White-headed Duck also showed a high association with the open water areas and was never found close to saltmarshes and Scirpus spp. and only a few broods were detected near a bare shoreline. Marbled Teal was found in all the microhabitats, especially broods, which were highly variable in their habitat selection.

Table 2. Models selected by the AIC criteria to explain the density of the Marbled Teal based on key features of the ponds. Dependent variable is the density of birds per 100 ha ranked to normalise the variable. We included as independent variables the percentage of open water, the surface of the ponds logarithmically modified (Lsup) and their quadratic effects. We show the results for broods (1999, $n=28$ ), one wintering (1998-1999, $n=27$ ) and one breeding season (1999, $n=28$ ). Percentage of explained deviance, AIC and $\triangle$ AIC of each model are also shown.

\begin{tabular}{|c|c|c|c|c|c|c|}
\hline & \multicolumn{2}{|c|}{ Adults winter } & \multicolumn{2}{|c|}{ Adults breeding } & \multicolumn{2}{|l|}{ Broods } \\
\hline & Coefficient & $P$ & Coefficient & $P$ & Coefficient & $P$ \\
\hline Lsup & -10.060 & 0.02 & -3.914 & 0.171 & 2.947 & 0.013 \\
\hline Lsup2 & 4.723 & 0.006 & 3.267 & 0.006 & & \\
\hline $\mathrm{AIC}(\triangle \mathrm{AIC})$ & \multicolumn{2}{|c|}{$174.07(6.64)$} & \multicolumn{2}{|c|}{$163.03(6.78)$} & \multicolumn{2}{|c|}{$165.82(3.08)$} \\
\hline$\%$ Deviance & \multicolumn{2}{|c|}{31.0} & \multicolumn{2}{|c|}{48.93} & \multicolumn{2}{|c|}{21.60} \\
\hline
\end{tabular}


Table 3. Models selected by the AIC criteria to explain the density of White-headed Duck based on key features of the ponds. The dependent variable is the density of birds per 100 ha ranked to normalise the variable. We included as independent variables the percentage of open water $(\mathrm{OW})$, the surface of the ponds logarithmically modified (Lsup) and their quadratic effects. We show the results for broods (1999, $n=28$ ), one wintering (1998-1999, $n=27$ ) and one breeding season (1999, $n=28)$. Percentage of explained deviance, AIC and $\triangle$ AIC of each model are also shown.

\begin{tabular}{|c|c|c|c|c|c|c|}
\hline & \multicolumn{2}{|c|}{ Adults winter } & \multicolumn{2}{|c|}{ Adults breeding } & \multicolumn{2}{|l|}{ Broods } \\
\hline & Coefficient & $P$ & Coefficient & $P$ & Coefficient & $P$ \\
\hline Lsup & -4.650 & 0.05 & -12.443 & 0.026 & -3.489 & 0.249 \\
\hline Lsup2 & 3.577 & $<0.001$ & $4 \cdot 304$ & 0.045 & 3.098 & 0.011 \\
\hline OW & & & -0.671 & 0.033 & & \\
\hline $\mathrm{OW}^{2}$ & & & 0.007 & 0.029 & & \\
\hline $\mathrm{AIC}(\triangle \mathrm{AIC})$ & \multicolumn{2}{|c|}{138.35 (14.05) } & \multicolumn{2}{|c|}{$198.38(2.84)$} & \multicolumn{2}{|c|}{$163.90(5.31)$} \\
\hline$\%$ Deviance & \multicolumn{2}{|c|}{68.45} & \multicolumn{2}{|c|}{29.12} & \multicolumn{2}{|c|}{$47 \cdot 31$} \\
\hline
\end{tabular}

Throughout the study, there were major spatial and temporal fluctuations in wetland depth. The average depth where the Marbled Teal was found was similar to that of the areas surveyed (Figure 6), while the average depth for the White-headed Duck was always significantly higher $(Z=3.06$, $P=0.0022, n=12)$. No White-headed Ducks were found in depths below $20 \mathrm{~cm}$ and no Marbled Teals were found in areas deeper than $75 \mathrm{~cm}$. The broods showed a similar pattern. Marbled Teal broods selected areas about 30-45 cm deep while White-headed Duck preferred depths of 50-65 cm (Figure 6).

\section{Discussion}

Marbled Teal and White-headed Duck have a similar geographical distribution across Eurasia and Africa (Kear 2005) and many wetland areas are important for both species, especially during the
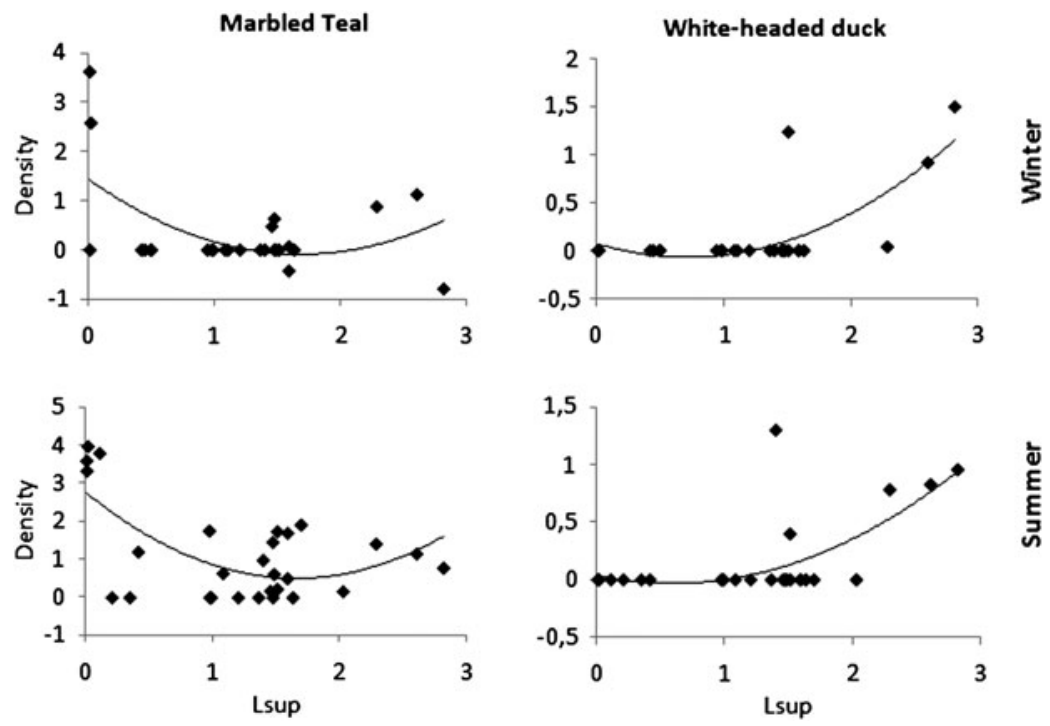

Figure 4. Density ( $\log _{10}$ [number individuals / 100 ha]) of adult Marbled Teal and White-headed Duck against the $\log _{10}$ surface area of the pond for winter 1998-1999 and summer 1999, showing quadratic curves fitted according to the models of Table 2. 
Table 4. Savage Selectivity Index (Wi) for adults in each period. Indices below one indicate avoidance and above one positive selection. Statistical significance is given after Bonferroni correction as follows: ${ }^{*} P<0.05$, ${ }^{* *} P<0.01,{ }^{* *} P<0.001$. Open water $(\mathrm{OW})$, Block of Phragmites Reedbed (BR), Reed channels (RC), and Mixed zones (MIX).

\begin{tabular}{|c|c|c|c|c|c|c|c|c|c|}
\hline & & \multicolumn{2}{|c|}{$\begin{array}{l}\text { Winter } \\
\text { 1998-1999 }\end{array}$} & \multicolumn{2}{|c|}{$\begin{array}{l}\text { Winter } \\
\text { 1999-2000 }\end{array}$} & \multicolumn{2}{|c|}{ Summer 1999} & \multicolumn{2}{|c|}{ Summer 2000} \\
\hline & & $\mathrm{Wi}$ & $P$ & Wi & $P$ & Wi & $P$ & $\mathrm{Wi}$ & $P$ \\
\hline \multirow[t]{4}{*}{ Marbled Teal } & OW & 0.285 & $* * *$ & 0.034 & $* * *$ & 0.055 & $* * *$ & 0.116 & $* * *$ \\
\hline & $\mathrm{BR}$ & 2.045 & $* * *$ & 2.708 & $* * *$ & 1.307 & $* * *$ & 2.082 & $* * *$ \\
\hline & $\mathrm{RC}$ & $5 \cdot 590$ & $* * *$ & 4.375 & $* * *$ & $5 \cdot 481$ & $* * *$ & 2.043 & $* * *$ \\
\hline & MIX & 1.89 & $*$ & 0.505 & ns & 6.697 & $* * *$ & 2.649 & $* * *$ \\
\hline \multirow[t]{4}{*}{ White-headed Duck } & OW & 1.587 & $* * *$ & 1.646 & $* * *$ & 0.394 & $* * *$ & 1.012 & ns \\
\hline & $\mathrm{BR}$ & 0.000 & $* * *$ & 0.000 & $* * *$ & 1.553 & $* * *$ & 1.109 & ns \\
\hline & $\mathrm{RC}$ & 0.806 & ns & 0.012 & $* * *$ & 10.075 & $* * *$ & 1.306 & ns \\
\hline & MIX & 0.000 & $* * *$ & 0.000 & $* * *$ & 0.000 & $* * *$ & 0.000 & $* * *$ \\
\hline
\end{tabular}

breeding season; i.e. there is considerable overlap between the lists of sites important for each species presented by Anstey (1989) and Green (1993). Both species breed in important numbers in brackish wetlands with luxuriant vegetation (Green 1997, 1998a), such as those of El Hondo (Torres and Moreno-Arroyo 2000, Madroño et al. 2004). However, we have found major differences in habitat selection between these two species, many of which can be explained by differences in behaviour. Marbled Teal are indeed "teal-like" in their small size, active flight and their tendency to feed in very shallow water (Green 1998c, 2000). White-headed Ducks are mostly associated with larger wetlands and with deeper areas within them (Green and Hughes 2001). The quadratic effect of wetland size observed for White-headed Ducks may be explained by a threshold effect, with birds absent from sites of $<20$ ha (although this applies only to the study area, and the species uses such small sites in some areas of southern Spain). Benthic chironomid larvae on which White-headed Ducks feed by diving (Sánchez et al. 2000) are likely to increase in biomass with depth (Green and Hilton 1998, Green et al. 1999b, Fuentes et al. 2004), making the central areas of the larger and deeper ponds attractive foraging habitat for this bird. Hence the higher average depth in relation to Marbled Teal and the average depth of the study ponds where the White-headed Duck was observed. White-headed Ducks are also likely to avoid small, shallow wetlands because their poor flight ability would make them particularly prone to predators (Fox et al. 1994). However, it is important to note that some wetlands of small size close to the study

Table 5. Savage Selectivity Index (Wi) for chicks in each period. Indices $<_{1}$ indicate avoidance and $>_{1}$ positive selection. Statistical significance is given after Bonferroni correction as follows: ${ }^{*} P<0.05,{ }^{* *} P<0.01,{ }^{* * *} P<$ o.0o1. Open water (OW), Block of Phragmites Reedbed (BR), Reed channels (RC), and Mixed zones (MIX).

\begin{tabular}{|c|c|c|c|c|c|}
\hline & & \multicolumn{2}{|c|}{ Summer 1999} & \multicolumn{2}{|c|}{ Summer 2000} \\
\hline & & Wi & $P$ & $\mathrm{Wi}$ & $P$ \\
\hline \multirow[t]{4}{*}{ Marbled Teal } & OW & 0.000 & $*$ & 0.093 & $* * *$ \\
\hline & $\mathrm{BR}$ & 2.439 & ns & 0.827 & ns \\
\hline & $\mathrm{RC}$ & 0.000 & ns & 2.778 & ns \\
\hline & MIX & 3.367 & ns & 8.953 & $* * *$ \\
\hline \multirow[t]{4}{*}{ White-headed Duck } & OW & 0.416 & $* * *$ & 0.432 & $* * *$ \\
\hline & $\mathrm{BR}$ & 1.785 & $* *$ & 2.060 & $* * *$ \\
\hline & $\mathrm{RC}$ & 6.635 & $* * *$ & 1.760 & $*$ \\
\hline & MIX & 0.000 & ns & 0.000 & $* *$ \\
\hline
\end{tabular}




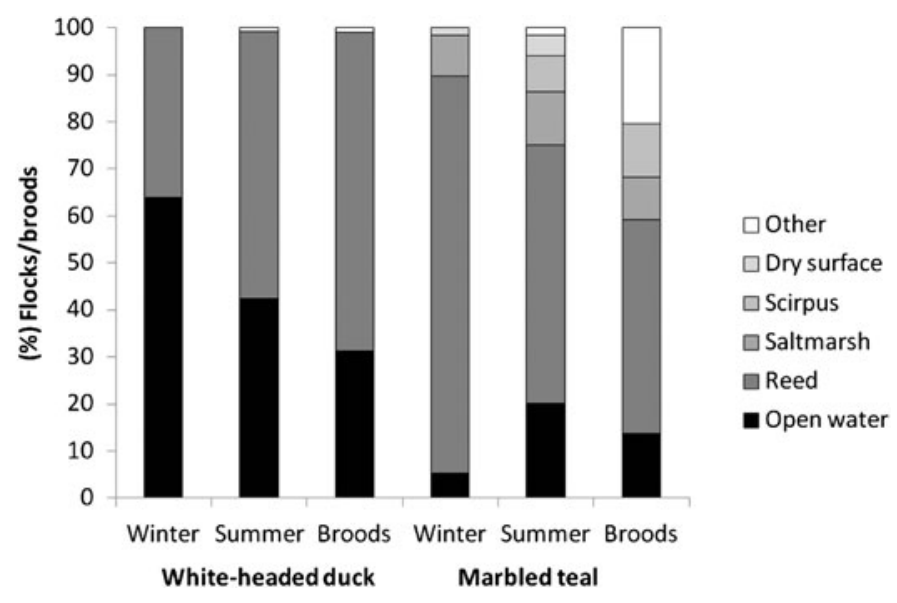

Figure 5. Association of flocks and broods of Marbled Teals and White-headed Ducks with different vegetation types and open water in both seasons. The figure represents the percentage of detections associated with each microhabitat type.

area are also used by the species and can be important for the conservation of Marbled Teal (Navarro 1994, Green and Navarro 1997).

In contrast, Marbled Teal showed a relative avoidance of ponds of intermediate size (2-10o ha). The smallest ponds are shallow and often temporary. When they are flooded, they have abundant and available seeds and invertebrates (Fuentes Sendín 2005, Fuentes et al. 2005) which form part of the diet of the Marbled Teal (Fuentes et al. 2004, Green and Sanchez 2003). The largest wetlands contain extensive open, deep areas that provide no cover and little food for Marbled Teal, since they can only access the top $30 \mathrm{~cm}$ of the water column (Green 1998c). Nevertheless, particularly high densities of Teal were found around the shoreline-open water interface of these larger ponds, where there are shallow waters and access to seeds concentrated along the shoreline, and invertebrates on the emergent vegetation.

Although pond surface area was overwhelmingly important in the models, it was confounded with average depth and the percentage of surface area covered by Phragmites. Pond size was

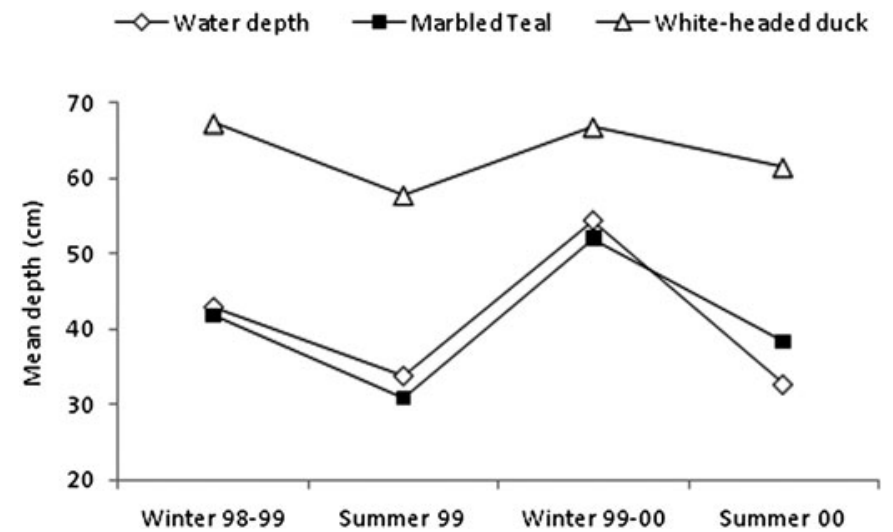

Figure 6. Average water depth in locations where flocks of Marbled Teal and White-headed Duck were observed. Average water depth of the surveyed areas is also shown. 
highly correlated with percentage of reed and average depth. Hence we cannot rule out the possibility that these parameters partly explain the effects of pond area. For example, within the depth range observed it can be expected that diving ducks such as White-headed Ducks would prefer the deepest ponds.

Although we were unable to use food supply as a predictor variable given the complexity of quantifying invertebrate and plant food in an adequate way in so many ponds, it is likely that resource availability plays a great part in the habitat use patterns recorded. For example, Marbled Teal are likely to prefer shallower areas with mixed vegetation because they allow greater access to food in sediments, and offer greater densities of small seeds such as those from Scirpus which are important dietary components (Green 1998a, Green and Selva 2000, Fuentes et al. 2004).

Both at macrohabitat and microhabitat level, Marbled Teal consistently avoided the central areas of open water, whereas White-headed Duck showed a strong selection for these areas in the nonbreeding period. During the breeding period, this selection by White-headed Duck was reversed and broods of all species also avoided the central zone. This strong switch in habitat use by Whiteheaded Duck can be seen at greater spatial scales, as in other range countries White-headed Ducks often winter in large lakes without emergent vegetation that do not provide suitable breeding habitat (Anstey 1989, Green et al. 1996).

Macrohabitats dominated by Phragmites were positively selected by both species in summer and by Marbled Teal in winter, especially the reed channels. The dense cover supplied by this vegetation provides suitable nesting habitat and refuge from disturbance and predators (Green and Hughes 2001). Furthermore, the invertebrate food supply in these areas is relatively high (Fuentes Sendín 2005, Sahuquillo et al. 2008), probably due partly to reduced summer water temperatures related to shading, protection from wave action, and the value of leaf litter as a substrate for detritivores. The mixed zone provided the most diverse vegetation and was selected by Marbled Teal but avoided by White-headed Duck, and is likely to be selected by Marbled Teal feeding on Scirpus litoralis seeds that are a major food item for adults (Fuentes et al. 2004). Marbled Teal broods probably selected this biotope because it is particularly shallow and provides the best opportunities for feeding on invertebrates. The analysis at microhabitat level was in accordance with the results for macrohabitats. Adults and chicks of both species were often detected close to reed formations, while Marbled Teal individuals also appeared near to Scirpus and saltmarsh plants.

When comparing seasons, the most striking changes in habitat use were a greater use of mixed zones by Marbled Teal in summer and a switch away from open water to various reed formations by White-headed Duck in summer. Therefore, habitat selection by the two species overlapped more in summer than winter. However, these two species are largely nocturnal foragers during winter (Green et al. 1999a, Green and El Hamzaoui 2000), and in this study we have only addressed diurnal habitat selection.

The seasonal changes in flock size observed are generally typical of ducks, with larger aggregations forming outside the breeding season. Observations for Marbled Teal were consistent with data from other years indicating that flock size tends to peak in the post-breeding period between September and November, before most of the birds move to North Africa to winter (Green 1993, 2000, Navarro and Robledano 1995, Green et al. 2004). Winter mortality is high for this species (Green et al. 2005), so that numbers returning to El Hondo in spring are generally much lower compared to the post-breeding censuses. In contrast, White-headed Duck are thought to have a resident population in Spain (Muñoz-Fuentes et al. 2005), although they regularly move between wetlands, largely in relation to fluctuations in water levels and food supply.

Many ducks are known to undergo brood amalgamation or creching (Beauchamp 1997, Green et al. 1999b). We found that White-headed Duck broods underwent a marked seasonal increase in size at El Hondo which resulted from creching, with females providing little if any care for ducklings after the first week or so. We observed creches of up to 70 ducklings of mixed ages. The White-headed Duck seems to be a case comparable to that of some shelducks and eiders (Afton and Paulus 1992). Brood amalgamation has previously been described in the related Ruddy Duck, but seems to be less extreme (Joyner 1977, Brua 2002). Brood mixing is more likely as brood 
density increases (Afton and Paulus 1992), and the density of White-headed Duck broods was especially high in El Hondo in 200o. In situations in which brood density was much lower, Amat and Sánchez (1982) found that broods were attended by females for 15-20 days. It is likely that decisions by females to desert their broods depend on the density of other broods and the possibilities of successfully hatching a further clutch, both of which are likely to vary between sites and years. For example, Lazli et al. (2011) did not detect brood amalgamation for the Whiteheaded Duck in a lower-density wetland in Algeria. In contrast, the brood size of Marbled Teal underwent seasonal declines which are probably related to a similar decline in clutch size that is well documented for this species (Green 1998b), although it is possible that an increase in the mortality rate of newly hatched ducklings could also be involved.

It is important to consider that in this type of study for cryptic species in densely vegetated areas, detection probability is not total and the results of the study could be biased. However, we tried to minimise this error: all surveys were performed by at least four experienced surveyors. Moreover, each point was surveyed at least three times (otherwise it was not included in the analyses) and only those surveys covering more than $65 \%$ of the area available for the waterbirds at each pond were used. The large size of the area surveyed and the difficulties with access did not allow an evaluation of detection probability using a method such as the double-observer approach (Nichols et al. 2000), but when possible, more than one person per point participated in the survey. We believe we have used the best survey design possible in these circumstances. However, true bird abundance may have been higher in areas where the vegetation present is denser. In most cases we found positive selection for areas with dense vegetation, which cannot be an artefact of such a detectability bias.

\section{Implications for management and conservation}

As expected given the differences in diet between the two species (Sánchez et al. 2000, Fuentes et al. 2004), we found major differences in habitat use between the two globally threatened ducks at El Hondo. In order to provide suitable habitat for both species, there is a need for integrated management of the whole wetland complex, maintaining diversity with a combination of large wetlands suitable for both species, and small ones suitable for Marbled Teal. The two main water reservoirs at the park are particularly important for both species, and subject to inappropriate management of water levels and quality (Colmenarejo et al. 2007). Under natural conditions, Mediterranean wetlands can have high annual and seasonal fluctuations in water level which are beneficial for biodiversity in the long term. However, the El Hondo wetland is semi-artificial and the water levels are largely regulated by the owners. In particular, water levels have often been artificially raised during the breeding season as water is diverted into the large ponds then later extracted for irrigation. Water levels should be regulated through the breeding season to prevent flooding of nests and rapid drainage. Reedbeds should be managed to retain the deeper channels, areas of mixed vegetation, and areas of extensive open water that are important to one or both species at different times of the year. Managers should also aim to ensure that small, luxuriant wetlands used by Marbled Teal are available at all times of the year, if necessary by rotating flooding cycles in different temporary wetlands.

\section{Acknowledgements}

This study was funded by the Consellería de Medio Ambiente, Generalitat Valenciana as part of a LIFE project. ES-G benefited from a FPU grant from the Spanish Ministry of Education and a FAPESP grant. Field observations were made by J. D. Navarro, R. Ortiz, J. Falcó, M. Alberdi, L. Fidel, M. Campderrós, J. C. Aranda, G. Ballesteros, R. Martínez, A. Izquierdo, M. A. Pavón, J. Zubieta and A. Quiles. Comments by David Serrano and Juan A. Amat helped to improve an earlier version of this manuscript. 


\section{References}

Afton, A. D. and Paulus, S. L. (1992) Incubation and brood care. Pp. 62-108 in B. D. Batt, A. D. Afton, M. G. Anderson, C. D. Ankney, D. H. Johnson, J. A. Kadlec, and G. L. Krapu, eds. Ecology and management of breeding waterfowl. Minnesota: University of Minnesota.

Amat, J. A. (1984) Actividad diurna de tres especies de patos buceadores en la Laguna de Zóñar (Córdoba, España meridional) durante el invierno. Miscelanea Zoologica 8: 203-211.

Amat, J. A. and Sanchez, A. (1982) Biológía y ecología de la Malvasía Oxyura leucocephala en Andalucía. Doñana Acta Vertebr. 9: 251-320.

Anstey, S. (1989) The status and conservation of the White-headed Duck Oxyura leucocephala. Slimbridge, UK: International Waterfowl and Wetlands Research Bureau. (IWRB Special Publication No. 10).

Armengol, X., Antón-Pardo, M., Atiénzar, F., Echevarrías, J. L. and Barba, E. (2008) Limnological variables relevant to the presence of the endangered white-headed duck in the southeastern Spanish wetlands during a dry period. Acta Zool. Acad. Sci. H. 54: 45-6o.

Ballesteros, G., Cabrera, M., Echevarría, J. L., Lorenzo, J. A., Raya, C., Torres Esquivias, J. A. and Viedma, C. (2008) Tarro canelo, cerceta pardilla, porrón pardo, malvasía cabeciblanca y focha moruna en España. Población en 2007 y método de censo. Madrid: SEO/BirdLife.

Beauchamp, G. (1997) Determinants of intraspecific brood amalgamation in waterfowl. The Auk 114: 11-21.

BirdLife International (2008a) Marmaronetta angustirostris. In IUCN 2010. IUCN Red List of threatened species. Version 2010.4. $<$ www.iucnredlist.org $>$. Downloaded on OI March 2011.

BirdLife International (2008b) Oxyura leucocephala. In IUCN 2010. IUCN Red List of threatened species. Version 2010.4. <www. iucnredlist.org > . Downloaded on о1 March 2011.

Brua, R. B. (2002) Ruddy Duck. The birds of North America, No. 696. The American
Ornithologists' Union. Cornell Laboratory of Ornithology and The Academy of Natural Sciences.

Block, W. M. and Brennan, L. A. (1993) The habitat concept in ornithology: theory and applications. Pp. 35-91 in D. M. Power, ed. Current ornithology. Vol. I1. New York: Plenum Press.

Burnham, K. P. and Anderson, D. R. (1998) Model selection and inference. A practical information-theoretic approach. New York: Springer-Verlag.

Castro, H., Nevado, J. C., Paracuellos, M. and López, J. M. (1994) La Malvasía (Oxyura leucocephala) en la provincia de Almería. Evolución poblacional, nidificación y selección de hábitat. Oxyura 7: 119-133.

Caughley, G. (1994) Directions in conservation biology. J. Anim. Ecol. 63: 215-244.

Cirujano, S., Moreno, M., Rubio, A. and Echevarrías, J. L. (2005) Plan de gestión continuada del carrizo en el Parque Natural El Hondo (Alicante). I Jornadas Científicas Parque Natural de El Hondo. Crevillente, 22-24 de febrero de 2005.

Colmenarejo, M. F., Sánchez, E., Borja, R., Travieso, L., Cirujano, S., Echevarrias, J. L., Rubio, A. and González, M. G. (2007) Evaluation of the quality of the water in El Hondo Natural Park located in the east of Spain. J. Environ. Sci. Heal. A 42: 969-981.

Fox, A. D., Green, A. J., Hughes, B. and Hilton, G. (1994) Rafting as an antipredator response in the White-headed Duck Oxyura leucocephala. Wildfowl 45: 232-241.

Fuentes, C., Sánchez, M. I., Selva, N. and Green, A. (2004) The diet of the Marbled Teal Marmaronetta angustirostris in southern Alicante, eastern Spain. Rev. Écol. (Terre Vie) 59: 475-490.

Fuentes, C., Green, A. J., Orr, J. and Olafosson, J. S. (2005) Seasonal variation in species composition and larval size of the benthic chironomid communities in brackish wetlands in Southern Alicante, Spain. Wetlands 25: 289-296.

Fuentes Sendín, C. (2005) Ecología de la Cerceta pardilla (Marmaroneta angustirostris) y de la Malvasía cabeciblanca (Oxyura leucocephala) en los humedales del Baix 
Vinalopó, Alicante. PhD thesis. University of Alicante, Spain.

Green, A. J. (1993) The status and conservation of the Marbled Teal Marmaronetta angustirostris. Slimbridge, UK: International Waterfowl and Wetlands Research Bureau. (IWRB Special Publication No. 23).

Green, A. J. (1997) Brood attendance and brood care in the Marbled Teal, Marmaronetta angustirostris. J. Ornithol. 138: 443-449.

Green, A. J. (1998a) Habitat selection by the Marbled Teal Marmaronetta angustirostris, Ferruginous Duck Aythya nyroca and other ducks in the Göksu Delta, Turkey in late summer. Rev. Ecol. (Terre Vie) 53: 225-243.

Green, A. J. (1998b) Clutch size, brood size and brood emergence in the Marbled Teal Marmaronetta angustirostris in the Marismas del Guadalquivir, southwestern Spain. Ibis 140: 670-675.

Green, A. J. (1998c) Comparative feeding behaviour and niche organization in a Mediterranean duck community. Can. J. Zool. 76: 500-507.

Green, A. J. (2000) The habitat requirements of the Marbled Teal (Marmaronetta angustirostris), Ménétriès, a review. Pp: 131-140 in F. A. Comín, J. A. Herrera and J. Ramírez, eds. Limnology and aquatic birds: monitoring, modelling and management. Proc. 2nd SIL Int. Cong. Mérida, Mexico: Universidad Autónoma del Yucatán.

Green, A. J. and Anstey, S. (1992) The status of the White-headed Duck Oxyura leucocephala. Bird Conserv. Internatn. 2: 185-200.

Green, A. J. and El Hamzaoui, M. (200o) Diurnal behaviour and habitat use of nonbreeding Marbled Teal, Marmaronetta angustirostris. Can. J. Zool. 78: 2112-2118.

Green, A. J. and Hilton, G. M. (1998) Management procedures required to increase chironomid availability to waders feeding on artificial lagoons remain unclear. J. Appl. Ecol. 35: 9-12.

Green, A. J. and Hughes, B. (2001) Oxyura leucocephala White-headed Duck. BWP Update 3: 79-90.

Green, A. J. and Navarro, J. D. (1997) National censuses of the Marbled Teal Marmaronetta angustirostris in Spain. Bird Study 44:1: 80-87.
Green, A. J. and Sánchez, M. I. (2003) Spatial and temporal variation in the diet of Marbled Teal Marmaronetta angustirostris in the Western Mediterranean. Bird Study 50: 153-160.

Green, A. J. and Selva, N. (200o). The diet of post-breeding Marbled Teal Marmaronetta angustirostris and Mallard Anas platyrhynchos in the Göksu Delta, Turkey. Revue d'Ecologie, Terre et Vie 55: 161-169.

Green, A. J., Fox, A. D., Hilton, G. M., Hughes, B., Yarar, M. and Salathé, T. (1996) Threats to Burdur Lake ecosystem, Turkey and its waterbirds, particularly the White-headed Duck Oxyura leucocephala. Biol. Conserv. 76: 241-252.

Green, A. J., Fox, A. D., Hughes, B. and Hilton, G. M. (1999a) Time-activity budgets and site selection of White-headed Ducks Oxyura leucocephala at Burdur Lake, Turkey in late winter. Bird Study 46: 62-73.

Green, A. J., Navarro, J. D., Dolz, J. C. and Aragoneses, J. (1999b) Brood emergence patterns in a Mediterranean duck community. Bird Study 46: 116-118.

Green, A. J., Fuentes, C., Figuerola, J., Viedma, C. and Ramón, N. (2005) Survival of Marbled Teal (Marmaronetta angustirostris) released back into the wild. Biol. Conserv. 121: 595-601.

Green, A. J., Fuentes, C., Vázquez, M., Viedma, C. and Ramón, N. (2004) Use of wing tags and other methods to mark Marbled Teal Marmaronetta angustirostris in Spain. Ardeola 51: 191-202.

Hastie, T. and Tibshirani, R. (1990) Generalized additive models. London, UK: Chapman and Hall. (Monographs on Statistics and Applied Probability).

Hildén, O. (1965) Habitat selection in birds. Ann. Zool. Fenn. 2: 53-75.

Joyner, D. E. (1977) Behavior of Ruddy Duck broods in Utah. The Auk 94: 343-349.

Kear, J. (2005) Bird families of the world: ducks, geese, swans and screamers. Oxford, UK: Oxford University Press.

Lazli, A., Boumezbeur, A., Pérennou, C. and Moali, A. (2011) Biologie de la réproduction de l'Érismature à tête blanche Oxyura leucocephala au Lac Tonga (Algérie). Rev. Écol. (Terre Vie) 66: 255-265. 
Madroño, A., González, C. and Atienza, J. C. (2004) Libro rojo de las aves de España. Madrid, Spain: Dirección General para la Biodiversidad-SEO/Birdlife.

Manly, B. F. J., McDonald, L. L. and Thomas, D. L. (1993) Resource selection by animals. London, UK: Chapman and Hall.

Martí, R. and Del Moral, J. C. (2003) La invernada de aves acuáticas en España. Madrid, Spain: Dirección General de Conservación de la Naturaleza-SEO/BirdLife. Ed. Organismo Autónomo Parques Nacionales, Ministerio de Medio Ambiente.

Martí, R. and Del Moral, J. C. (2004) Atlas de las aves reproductoras de España. Madrid, Spain: Sociedad Española de Ornitología.

McCullagh, P. and Nelder, J. A. (1989) Generalized linear models. London, UK: Chapman and Hall.

Meléndez-Pastor, I., Navarro-Pedreño, J., Gómez, I. and Koch, M. (2010) Detecting drought induced environmental changes in a Mediterranean wetland by remote sensing. Appl. Geogr. 30: 254-262

Mildenstein, T. L., Stier, S. C., Nuevo-Diego, C. E. and Mills, L. S. (2005) Habitat selection of endangered and endemic large flying-foxes in Subic Bay, Philippines. Biol. Conserv. 126: 93-102

Muñoz-Fuentes, V., Green, A. J., Negro, J. J. and Sorenson, M. D. (2005) Population structure and loss of genetic diversity in the endangered white-headed duck, Oxyura leucocephala. Conserv. Genet. 6: 999-1015.

Muñoz-Fuentes, V., Vilà, C., Green, A. J., Negro, J. J. and Sorenson, M. D. (2007) Hybridization between white-headed ducks and introduced ruddy ducks in Spain. Mol. Ecol. 16: 629-638.

Muñoz-Fuentes, V., Green, A. J. and Sorenson, M. D. (2008) Comparing the genetics of wild and captive populations of white-headed ducks Oxyura leucocephala: consequences for recovery programmes. Ibis 150: 807-815.

Navarro, J. D. (1994) La reproducción de la Cerceta Pardilla (Marmaronetta angustirostris) en los humedales sudalicantinos. Actas de las XII Jornadas Ornitológicas Españolas (Almerimar; El Ejido-Spain): 279-282.

Navarro, J. D. and Robledano, F., coordinators. (1995) La Cerceta Pardilla Marmar- onetta angustirostris en España. Madrid: ICONA-MAPA.

Nichols, J. D., Hines, J. E., Sauer, J. R., Fallon, J. W., Fallon, J. E. and Heglund, P. J. (2000). A double-observer approach for estimating detection probability and abundance from point counts. Auk 117: 393-408.

Onorato, D. P., Criffield, M., Lotz, M., Cunningham, M., McBride, R., Leone, E. H., Bass, O. L. and Hellgren, E. C. (2010) Habitat selection by critically endangered Florida panthers across the diel period: implications for land management and conservation. Anim. Conserv. 14: 196-205.

R Development Core Team (2007) R: A language and environment for statistical computing.Vienna, Austria: R Foundation for Statistical Computing.

Sahuquillo, M., Miracle, M. R., Rieradevall, M. and Kornijow, R. (2008) Macroinvertebrate assemblages on reed beds, with special attention to Chironomidae (Diptera) in Mediterranean shallow lakes. Limnetica 27: 239250.

Sánchez, M. I., Green, A. J. and Dolz, J. C. (2000) The diets of the White-headed Duck Oxyura leucocephala, Ruddy Duck O. jamaicensis and their hybrids from Spain. Bird Study 47: 275-284.

Torralva, M., Oliva-Paterna, F. J., Miñano, P. A., Andreu, A., Caballero, A., Egea, A. and Verdiell, D. (2002) Estudio de la situación de las carpas (Cyprinus carpio) y su efecto sobre la malvasía cabeciblanca (Oxyura leucocephala) en el Parque Natural El Hondo: componente ictiofaunístico. Valencia, Spain: Conselleria de Medi Ambient.

Torres, J. A. and Moreno-Arroyo, B. (200o) La recuperación de la malvasía cabeciblanca (Oxyura leucocephala) en España durante el último decenio del siglo XX. Oxyura 10: 5-51.

Ursúa, E., Serrano, D. and Tella, J. L. (2005) Does land irrigation actually reduce foraging habitat for breeding Lesser Kestrel. Biol. Conserv. 122: 643-648.

Wintle, B. A., Elith, R. J. and Potts, J. (2005) Fauna habitat modeling and mapping; a review and case study in the Lower Hunter Central Coast region of NSW. Austral. Ecol. 30: 719-738 


\section{ESTHER SEBASTIÁN-GONZÁLEZ*}

Ecology Area, Department of Applied Biology, Miguel Hernández University, Ctra. Beniel Km 3.2, E-03312 Orihuela, Alicante, Spain.

Present address: Departamento da Ecologia. Universidade de São Paulo. Rua do Matão, Travessa 14, $n^{\circ}$ 321, Departamento de Ecologia Cidade Universitária, CEP 05508-900, São Paulo, Brazil.

\section{CRISTINA FUENTES, ANDY J. GREEN}

Department of Wetland Ecology, Doñana Biological Station EBD-CSIC, Avenida Américo Vespucio s/n, E-41092 Sevilla, Spain.

\section{MARCOS FERRÁNDEZ}

Centro de recuperación de fauna de Santa Faz. Generalitat Valenciana. Crtra. Alicante Valencia km. 86,400. 03559 Santa Faz Alicante, Spain.

\section{JOSÉ L. ECHEVARRÍAS}

Consellería de Infraestructuras, Territorio y Medio Ambiente. Oficina Comarcal de Medio Ambiente de Crevillent. Plaza Doctor Mas Candela, 15. 03330 Crevillent, Spain.

*Author for correspondence; e-mail: esebastian@umh.es

Received 24 October 2011; revision accepted 9 April 2012; Published online 16 July 2012 